\title{
Comparing the $\mathrm{ZnO} / \mathrm{Fe}(\mathrm{VI}), \mathrm{UV} / \mathrm{ZnO}$ and $\mathrm{UV} / \mathrm{Fe}(\mathrm{VI})$ processes for removal of Reactive Blue 203 from aqueous solution
}

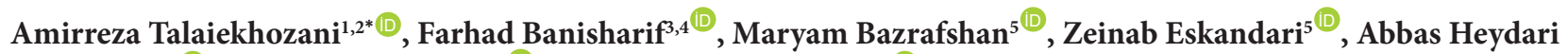 \\ Chaleshtari $^{5}{ }^{\mathbb{D}}$, Ghasem Moghadam ${ }^{6}$, Ali Mohammad Amani ${ }^{2,7}$ \\ ${ }^{1}$ Department of Civil Engineering, Jami Institute of Technology, Isfahan, Iran \\ ${ }^{2}$ Center of Applied Nanobiophotonics, Shiraz University of Medical Sciences, Shiraz, Iran \\ ${ }^{3}$ Department of Research and Development, Nirouchlor, Isfahan, Iran \\ ${ }^{4}$ Department Chemical Engineering, Iran University of Science and Technology, Tehran, Iran \\ ${ }^{5}$ Department of Chemical Engineering, Jami Institute of Technology, Isfahan, Iran \\ ${ }^{6}$ Young Researchers and Elites Club, Islamic Azad University, Shahrekord Branch, Shahrekord, Iran \\ ${ }^{7}$ Department of Medical Nanotechnology, School of Advance Medical Sciences and Technologies, Shiraz University of Medical Sciences, \\ Shiraz, Iran
}

\begin{abstract}
Background: Wastewater contaminated with dyes such as Reactive Blue 203 can produce a lot of health problems if it is released into the environment without a suitable treatment. Although there are several studies on dye removal from wastewater, removal of Reactive Blue 203 has not been investigated by hybrid methods. Therefore, the aim of this study was to investigate the removal of Reactive Blue 203 from aqueous solution, using combined processes of zinc oxide $(\mathrm{ZnO})$ nanoparticles, $\mathrm{Fe}(\mathrm{VI})$ oxidation process, and $\mathrm{UV}$ radiation. Methods: The removal of dye from aqueous solution using $\mathrm{ZnO}$ nanoparticles, $\mathrm{Fe}(\mathrm{VI})$ oxidation process, and UV radiation was individually evaluated. Then, the results of combined methods were compared. Hydraulic retention time (HRT), $\mathrm{pH}$, and temperature were the most important factors which were investigated in this study.

Results: $\mathrm{ZnO}$ nanoparticles, $\mathrm{Fe}(\mathrm{VI})$ oxidation process, and UV radiation were able to remove $97 \%, 71 \%$, and $47 \%$ of the dye in the optimal conditions, respectively. Also, the removal of dye using combination of $\mathrm{Fe}(\mathrm{VI})$ oxidation process/UV radiation, $\mathrm{ZnO}$ nanoparticles/Fe(VI) oxidation process, and $\mathrm{ZnO}$ nanoparticles/UV radiation under optimum conditions was $100 \%$. It seems that the combined methods were significantly more effective than the methods alone for removal of dye from water.

Conclusion: UV radiation alone is a simple and efficient method for removal of Reactive Blue 203 from water. Removal of Reactive Blue 203 using Fe(VI) oxidation process can be completed in a fraction of second, therefore, it can be categorized as a rapid reaction.

Keywords: Wastewater, Ultraviolet rays, Zinc oxide, Adsorption

Citation: Talaiekhozani A, Banisharif F, Bazrafshan M, Eskandari Z, Heydari Chaleshtari A, Moghadam $\mathrm{G}$, et al. Comparing the $\mathrm{ZnO} / \mathrm{Fe}(\mathrm{VI})$, $\mathrm{UV} / \mathrm{ZnO}$ and $\mathrm{UV} / \mathrm{Fe}(\mathrm{VI})$ processes for removal of Reactive Blue 203 from aqueous solution. Environmental Health Engineering and Management Journal 2019; 6(1): 27-39. doi: 10.15171/EHEM.2019.04.
\end{abstract}

Article History:

Received: 27 October 2018 Accepted: 25 December 2018 ePublished: 15 January 2019

\section{Introduction}

Widespread use of chemicals in various industries in the world results in the production of a large amount of wastewater (1). There is a large amount of chemicals in industrial wastewater. These chemical compounds can be toxic, carcinogenic, teratogenic, and mutagenic (2). Therefore, it is necessary to treat wastewater before its release in the environment (3). Dyes are chemical compounds that make the wastewater colored. The use of dyes for textile fabrics turns back to $10000 \mathrm{BC}$. The Reactive Blue 203 dye is one of the most common used dyes in the textile industry and its molecular structure is shown in Figure 1.

Although dyes are usually produced in the form of solid powder, they should be dissolved into the aquatic solution for painting the fabric. Therefore, textile industries are responsible for producing a large amount of contaminated wastewater that can increase serious environmental issues (4). Most dyes, even in extreme light conditions, are very stable. For this reason, they cannot be effectively eliminated by physical, chemical, and biological methods (5). A wide range of dye concentration between 30 and $714 \mathrm{mg} / \mathrm{L}$ has been reported in different studies $(6,7)$. Different methods such as oxidation, adsorption, and 


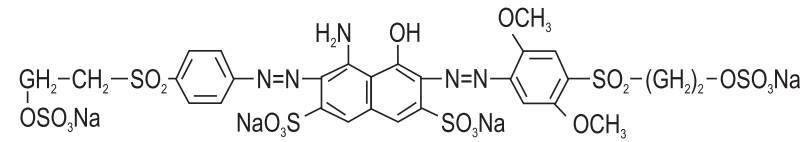

Figure 1. Molecular structure of Reactive Blue 203.

photo-oxidation processes are usually used to remove dye from wastewater. Oxidation processes are considered as a popular method for the treatment of water-soluble dyes (8). Ozone, chlorine, chlorine dioxide, and hydrogen peroxide are among the well-known oxidants used to treat colored wastewater. Although chlorine is an inexpensive oxidizer, trihalomethanes (THMs) are formed as a byproduct in the wastewater treatment (9). Since THMs have carcinogenic effects, they are considered as the environmental pollutants. Therefore, the use of chlorine as an oxidizing agent can remove a wide range of pollutants and generate new pollutants in wastewater. Ozone and chlorine dioxide have no side effects but they are very expensive (10). Recent studies have introduced new oxidizing agents that can be used in the wastewater treatment. $\mathrm{Fe}(\mathrm{VI})$ is a chemical that has the highest oxidation power in the acidic environment compared to the other oxidants (11). This chemical not only oxidizes organic compounds, but also kills microorganisms (12). In aqueous solutions, $\mathrm{Fe}(\mathrm{VI})$ converts to $\mathrm{Fe}(\mathrm{III})$, which is known as a coagulant (10). $\mathrm{Fe}(\mathrm{VI})$ can be used for oxidation, coagulation, and disinfection of urban and industrial wastewater in one reactor. Many attempts have been made to use the $\mathrm{Fe}(\mathrm{VI})$ oxidation process to remove various contaminants from the wastewater $(11,13-21)$.

Photocatalytic oxidation is another popular method that has been widely used to remove dye from wastewater. Photocatalytic oxidation is defined as chemical change through light radiation, including visible and invisible wavelengths (22). Nowadays, researchers are studying nanosemiconductor photocatalysts since they have several exciting properties (23). In many cases, particles between 1 to $100 \mathrm{~nm}$ in size are called nanoscale particles. Solid particles are composed of atoms and molecules. By reducing the particle size, solid particles exhibit different characteristics, probably due to changes in the bonding state of the atoms and molecules of the particles. The nanomaterials have a large surface area and are totally different from bulk materials (24). Therefore, the nanomaterials show incredible efficiency for different uses (25). There are many known semiconductor such as zinc oxide $(\mathrm{ZnO})$ and titanium oxide $\left(\mathrm{TiO}_{2}\right)$, which have a large energy gap. Such semiconductors show appropriate results for different applications like paints, gas sensor, biosensor, sunscreen, and solar cells $(26,27)$. From commercial aspect, $\mathrm{ZnO}$ has priority to other semiconductors as it is very cheap. For this reason, it was used in this study. Nanoparticles of $\mathrm{ZnO}$ are prepared by several methods including alkaline deposition, thermal decomposition, micro-emulsion, organic-zinc hydrolysis, and thermal degradation of the plasma. Some studies claimed that existing $\mathrm{ZnO}$ nanoparticles can enhance some certain removal processes of pollutants from water $(22,28)$. Darvishi Cheshmeh Soltani et al reported that the treatment of textile wastewater can be improved by using $\mathrm{ZnO}$ nanoparticles (29). Darvishi Cheshmeh Soltani et al used a rectangular photo-reactor equipped with carbon black (CB)/ZnO nanocomposite film to degrade methyl orange dye (30). They found that the optimum initial dye concentration, reaction time, $\mathrm{CB} / \mathrm{ZnO}$ ratio and initial $\mathrm{pH}$ were $13 \mathrm{mg} / \mathrm{L}, 95$ minutes, 0.05 , and 5 , respectively. They reported that under optimum condition nearly $80 \%$ of methyl orange dye could be removed by $\mathrm{CB} /$ $\mathrm{ZnO}$. The ability of $\mathrm{ZnO}$ nanoparticles can be enhanced by ultraviolet radiation. UV is a powerful radiation that is applied for wastewater treatment alone or with photocatalytic oxidants (31). Talaiekhozani et al reported that UV radiation can be efficiently used to remove hydrogen sulfide from municipal wastewater (32). Using UV radiation with photocatalytic oxidants such as $\mathrm{ZnO}$ or $\mathrm{TiO}_{2}$ can improve pollutants removal (33). UV causes a large number of chemical interactions. These interactions are more intense at a wavelength about $0.3 \mu \mathrm{m}$.

Although many studies have already been done on the removal of pollutants using UV radiation, $\mathrm{Fe}(\mathrm{VI})$ oxidation process, and $\mathrm{ZnO}$ nanoparticles (34-39), but no study has investigated the effect of combination of these methods to remove dye from wastewater. In this study, the effects of $\mathrm{Fe}(\mathrm{VI})$ oxidation process, $\mathrm{ZnO}$ nanoparticles, and UV radiation and their combination on the removal of Reactive-Blue 203 dye were investigated.

\section{Materials and Methods}

Analytical methods

A synthetic wastewater was used for the experiments. To prepare synthetic wastewater, a suitable amount of Reactive Blue 203 dye was dissolved into distilled water to provide a solution of $39 \mathrm{mg} / \mathrm{L}$. All of the chemicals except Reactive Blue 203 and $\mathrm{ZnO}$ nanoparticles were purchased from Merck Company. Reactive Blue 203 was purchased from Alwan Company (Hamedan, Iran). ZnO nanoparticles were purchased from Scharlau Company (Barcelona, Spain) with a purity of $99.9 \%$. Several studies have shown that Reactive Blue 203 can be measured by a spectrophotometer (40). Therefore, the concentration of dye in synthetic wastewater was measured using a UVVIS spectrophotometer (UNICO model S2100 SUV) at a wavelength of $631 \mathrm{~nm}$. To measure the amount of UV radiation, a GBT5/OFRG3 8W UV meter was used. In this study, for all experiments, equation 1 was used to determine the removal efficiency of dye.

$$
R E=\frac{C_{1}-C_{2}}{C_{1}} \times 100
$$

where $C_{1}$ is the initial concentration of dye $(\mathrm{mg} / \mathrm{L}), C_{2}$ is the secondary concentration of dye $(\mathrm{mg} / \mathrm{L})$, and $R E$ is the 
removal efficiency of dye from synthetic wastewater (\%). The experiments were performed as batch and one factor at a time (OFAT) method. Scanning electron microscope (SEM), X-ray diffraction (XRD), and Brunauer-EmmettTeller (BET) test are usually used to analyze some characteristics such as size and specific surface area of nanoparticles (5). In this study, the characteristics of $\mathrm{ZnO}$ nanoparticles were analyzed using SEM, X-RD, and BET.

\section{UV radiation}

Since UV radiation cannot pass through the glass, a dish $(20 \times 12 \times 2.5 \mathrm{~cm})$ was used to study the dye removal using UV radiation, which is called UV container in this study. The UV container had a low depth and high surface. The UV lamp was installed in a distance of few millimeters of the synthetic wastewater surface.

\section{$\mathrm{pH}$}

Seven UV containers containing $100 \mathrm{~mL}$ of synthetic wastewater were prepared. Then, $\mathrm{pH}$ of synthetic wastewater in the containers was adjusted to $1,3,5,7,9$, 11 , and 13 by adding a suitable amount of $4 \mathrm{~N}$ hydrochloric acid or $2 \mathrm{~N}$ sodium hydroxide. Next, the containers were placed under UV radiation with power of $170 \mathrm{~mW} / \mathrm{cm}^{2}$ at $23^{\circ} \mathrm{C}$ for 15 minutes. At the end, the dye concentration in the containers was measured.

\section{Hydraulic retention time}

Fourteen UV containers containing $100 \mathrm{~mL}$ of synthetic wastewater were prepared. Then, the $\mathrm{pH}$ of synthetic wastewater was adjusted to 13 by adding a suitable amount of $2 \mathrm{~N}$ sodium hydroxide. It should be noted that in this study, the optimum $\mathrm{pH}$ for dye removal using UV radiation was obtained to be 13 , therefore, this $\mathrm{pH}$ was used for the next experiments. Next, the containers were exposed to UV radiation with power of $170 \mathrm{~mW} / \mathrm{cm}^{2}$ at $23^{\circ} \mathrm{C}$ for 1 to 55 minutes. Eventually, the dye concentration in the containers was determined.

\section{Temperature}

Six UV containers containing $100 \mathrm{~mL}$ of synthetic wastewater were prepared. Then, $\mathrm{pH}$ of synthetic wastewater was adjusted to 13 . Next, the containers were exposed to UV radiation with power of $170 \mathrm{~mW} / \mathrm{cm}^{2}$ for 50 minutes at temperatures of $10,30,40,50,55$, and $60^{\circ} \mathrm{C}$, respectively. Finally, the concentration of remaining dye in the containers was measured.

\section{UV radiation}

Five UV containers containing $100 \mathrm{~mL}$ of synthetic wastewater were prepared. Then, $\mathrm{pH}$ was adjusted to 13 by $2 \mathrm{~N}$ sodium hydroxide. Next, the containers were exposed to $\mathrm{UV}$ radiation with power of 10 to $170 \mathrm{~mW} / \mathrm{cm}^{2}$ at $23^{\circ} \mathrm{C}$ for 15 minutes. After that, the dye concentration in each container was measured.
$\mathrm{Fe}(\mathrm{VI})$ oxidation process

There are several effective factors on $\mathrm{Fe}(\mathrm{VI})$ oxidation process such as concentration of organic matter, $\mathrm{pH}$, $\mathrm{Fe}(\mathrm{VI})$ concentration, temperature, presence of impurities etc $(12,16-18)$. In this study, the effect of $\mathrm{pH}, \mathrm{Fe}(\mathrm{VI})$ concentration, hydraulic retention time (HRT), and temperature was investigated.

$\mathrm{pH}$

Eleven $250 \mathrm{~mL}$ Erlenmeyer flasks containing $100 \mathrm{~mL}$ of synthetic wastewater were prepared. Then, $\mathrm{pH}$ of synthetic wastewater was adjusted to 1 to 13 by adding a suitable amount of hydrochloric acid or sodium hydroxide, respectively. Next, $\mathrm{Fe}(\mathrm{VI})$ was added to each flask to obtain the concentration of $3.3 \mathrm{mg} / \mathrm{L}$. After that, the flasks were kept at $23^{\circ} \mathrm{C}$ for $15 \mathrm{~min}$. Finally, the concentration of remaining dye in the solutions was determined.

\section{$\mathrm{Fe}(\mathrm{VI})$ concentration}

Six $250 \mathrm{~mL}$ Erlenmeyer flasks containing $250 \mathrm{~mL}$ of synthetic wastewater were prepared. Then, $\mathrm{pH}$ of synthetic wastewater was adjusted to 1 by adding a suitable amount of hydrochloric acid. Next, 0.9, 1.5, 2, 2.7, 3.3, and $4 \mathrm{mg}$ of $\mathrm{Fe}(\mathrm{VI})$ was added to each flask, respectively. After that, the flasks were kept at $23^{\circ} \mathrm{C}$ for $15 \mathrm{~min}$. Eventually, the dye concentration in the flasks was measured.

\section{Hydraulic retention time}

Eleven $250 \mathrm{~mL}$ Erlenmeyer flasks containing $100 \mathrm{~mL}$ of synthetic wastewater were prepared. Then, $\mathrm{pH}$ of synthetic wastewater was adjusted to 1 by adding a suitable amount of hydrochloric acid. Next, Fe(VI) was added to the flasks to obtain the concentration of $3.3 \mathrm{mg} / \mathrm{L}$. After that, the flasks were kept at $23^{\circ} \mathrm{C}$ for 1 to 40 minutes, respectively. Finally, the concentration of remaining dye in each flask was determined.

\section{Temperature}

Six $250 \mathrm{~mL}$ Erlenmeyer flasks containing $100 \mathrm{~mL}$ of synthetic wastewater were prepared. Then $\mathrm{pH}$ of the synthetic wastewater in each flask was adjusted to 1 by adding a suitable amount of hydrochloric acid. Next, a suitable amount of $\mathrm{Fe}(\mathrm{VI})$ was added to each flask to obtain the concentration of $3.3 \mathrm{mg} / \mathrm{L}$. After that, the flasks were kept at temperatures of $23,30,40,50,60$, and $70^{\circ} \mathrm{C}$ for 15 minutes. Finally, the dye concentration in each flask was measured.

\section{$\mathrm{ZnO}$ nanoparticles}

$\mathrm{pH}$

Six $250 \mathrm{~mL}$ Erlenmeyer flasks containing $100 \mathrm{~mL}$ of synthetic wastewater were prepared. Then, $\mathrm{pH}$ of each flask was adjusted to $1,3,6,9,11$, and 13 , respectively. Next, $\mathrm{ZnO}$ nanoparticles were added to each flask to achieve the concentration of $200 \mathrm{mg} / \mathrm{L}$. Next, the flasks were incubated by a shaker incubator at $150 \mathrm{rpm}$ at $23^{\circ} \mathrm{C}$ 
for 15 minutes. Finally, the dye concentration in each flask was measured.

\section{$\mathrm{ZnO}$ concentration}

Nine $250 \mathrm{~mL}$ Erlenmeyer flasks containing $100 \mathrm{~mL}$ of synthetic wastewater were prepared. Then, a suitable amount of $\mathrm{ZnO}$ nanoparticles was added to each flask to obtain the concentration of 200 to $1000 \mathrm{mg} / \mathrm{L}$, respectively. Next, $\mathrm{pH}$ was adjusted to 9 by adding sodium hydroxide. After that, the flasks were incubated by a shaker incubator at $150 \mathrm{rpm}$ at $23^{\circ} \mathrm{C}$ for 15 minutes. Ultimately, the concentration of remaining dye in each flask was determined.

\section{Hydraulic retention time}

Six $250 \mathrm{~mL}$ Erlenmeyer flasks containing $100 \mathrm{~mL}$ of synthetic wastewater were prepared. Then, $\mathrm{pH}$ of synthetic wastewater was adjusted to 9 by adding a suitable amount of sodium hydroxide. After that, $\mathrm{ZnO}$ nanoparticles were added to each flask to achieve the concentration of $800 \mathrm{mg} / \mathrm{L}$. After that, the flasks were incubated by a shaker incubator at $150 \mathrm{rpm}$ at $23^{\circ} \mathrm{C}$ for 1 to 30 minutes, respectively. Then, the concentration of remaining dye in each flask was measured.

\section{Temperature}

Seven $250 \mathrm{~mL}$ Erlenmeyer flasks containing $100 \mathrm{~mL}$ of synthetic wastewater were prepared. Then, Fe(VI) was added to each flask to obtain the concentration of 800 $\mathrm{mg} / \mathrm{L}$. Next, the $\mathrm{pH}$ was adjusted to 9 by adding a suitable amount of sodium hydroxide. After that, the flasks were incubated by a shaker incubator at $150 \mathrm{rpm}$ for 15 minutes at temperatures of $10,20,30,40,50,60$, and $70^{\circ} \mathrm{C}$, respectively. Finally, the concentration of remaining dye in the flasks was measured.
Isotherm models

In this study, isotherm models of Langmuir, Freundlich, Temkin, Dubinin-Radushkevich (D-R), Generalized, and Jovanovic were investigated (Table 1). Freundlich isotherm has been empirically achieved. Freundlich isotherm is shown in Eq. 2. In this equation, $x / m$ is the amount of adsorbed adsorbate per adsorbent, $C_{e}$ is the equilibrium concentration of adsorbate in the solution after adsorption process, and $n$ and $K_{f}$ are constant coefficients of Freundlich isotherm. Eq. (2) is analogous of linear equation $(\mathrm{y}=\mathrm{ax}+\mathrm{b})$. The amount of $K_{f}$ and $n$ is calculated using plotting $\log (x / m)$ versus $\log \left(C_{e}\right)$. Langmuir isotherm is shown in Eq. 3. In this equation, $a$ and $b$ are constant coefficients of Langmuir isotherm. Eq. 3 is similar to the general linear equation; therefore, $a$ and $b$ can be calculated by plotting $C_{e}(x / m)$ versus $C_{e}$. The Temkin isotherm is shown in Eq. 4 . In this equation, $K_{T}$ is the equilibrium binding constant $(\mathrm{L} / \mathrm{mg})$ and constant $B_{1}$ is related to heat of adsorption. In this equation, the constants $K_{T}$ and $B_{1}$ can be calculated using a linear plot of $q_{e}$ versus $\ln \left(C_{e}\right)$. The $\mathrm{D}-\mathrm{R}$ isotherm is shown in Eq. 5 . In this equation, $q_{e}$ is $\mathrm{D}-\mathrm{R}$ constant and $\varepsilon$ can be calculated using Eq. 6. In Eq. 5 and $6, q_{e}$ is the maximum amount of adsorbate that can be adsorbed on the adsorbent, $B$ is the constant related to energy, $C_{e}$ is the equilibrium concentration $(\mathrm{mg} / \mathrm{L}), R$ is the universal gas constant that is equal to $8.314 \mathrm{~J} / \mathrm{mol} . \mathrm{K}$ and $T$ is temperature (Kelvin). The Generalized isotherm is shown in Eq. 7. In this equation, $K_{G}$ is the saturation constant ( $\mathrm{mg} / \mathrm{L}$ ), $N$ is the cooperative binding constant, $q_{\max }$ is the maximum adsorption capacity of the adsorbent $(\mathrm{mg} / \mathrm{g}), q_{e}(\mathrm{mg} / \mathrm{g})$ and $C_{e}(\mathrm{mg} / \mathrm{L})$ are the equilibrium dye concentrations in the soil and liquid phase, respectively. The values of $N$ and $K_{G}$ in Eq. 7 are obtained from the slope and intercept of the plots. Eq. 8 shows the linear form of the Jovanovic model, where

Table 1. The list of isotherms investigated in this study

\begin{tabular}{|c|c|c|}
\hline Isotherm Equations & Isotherm & Equation No. \\
\hline $\log \left(\frac{x}{m}\right)=\log K_{f}+\frac{1}{n} \log \left(C_{e}\right)$ & Freundlich & (2) \\
\hline$\frac{C_{e}}{(x / m)}=\frac{1}{a b}+\frac{1}{a} C_{e}$ & Langmuir & (3) \\
\hline$q_{e}=B_{1} \ln \left(K_{T}\right)+B_{1} \ln \left(C_{e}\right)$ & Temkin & (4) \\
\hline $\ln q_{e}=\ln q_{s}-B \varepsilon^{2}$ & D-R (Part 1) & (5) \\
\hline$\varepsilon=R T \ln \left(1+\frac{1}{C_{e}}\right)$ & D-R (Part 2) & (6) \\
\hline $\ln \left[\left(\frac{q_{\max }}{q_{e}}\right)-1\right]=\ln \left(K_{G}\right)-N \ln \left(C_{e}\right)$ & Generalized & (7) \\
\hline $\ln q_{e}=\ln q_{\max }-K_{J} C_{e}$ & Jovanovic & (8) \\
\hline
\end{tabular}


$C_{e}$ is the equilibrium concentration $(\mathrm{mg} / \mathrm{L}), K_{J}$ is constant coefficient of Jovanovic, $q_{e}$ is the amount of adsorbate that was adsorbed onto the adsorbent at equilibrium stage $(\mathrm{mg} / \mathrm{g})$, and $q_{\max }$ is the maximum adsorption capacity obtained from the plot of $\ln q_{e}$ versus $C_{e}$.

\section{Results}

\section{UV radiation}

The effect of HRT, UV radiation power, $\mathrm{pH}$, and temperature on the dye removal using UV radiation is shown in Figure 2. The results showed that the increase of $\mathrm{pH}$ had a negative effect on the dye removal efficiency (Figure 2a). The increased temperature between 10 and $60^{\circ} \mathrm{C}$ did not have a significant effect on the dye removal (Figure 2b). The dye removal efficiency was sharply increased when HRT increased between 1 and 15 minutes (Figure 2c). The UV power between 10 and $70 \mathrm{~mW} / \mathrm{cm}^{2}$ had a significant effect on the dye removal (Figure $2 \mathrm{~d}$ ).

\section{$\mathrm{Fe}(\mathrm{VI})$}

The effect of different factors including $\mathrm{pH}$, HRT, temperature, and concentration of $\mathrm{Fe}(\mathrm{VI})$ on the dye removal using $\mathrm{Fe}(\mathrm{VI})$ oxidation process is shown in Figure 3. The results showed that the dye removal efficiency using $\mathrm{Fe}(\mathrm{VI})$ sharply decreased when $\mathrm{pH}$ increased from 1 to 4 and 10 to 13 (Figure 3a). But the dye removal efficiency had a constant trend at $\mathrm{pH}$ values between 4 and 10 . The reaction between $\mathrm{Fe}(\mathrm{VI})$ and the dye could be completed
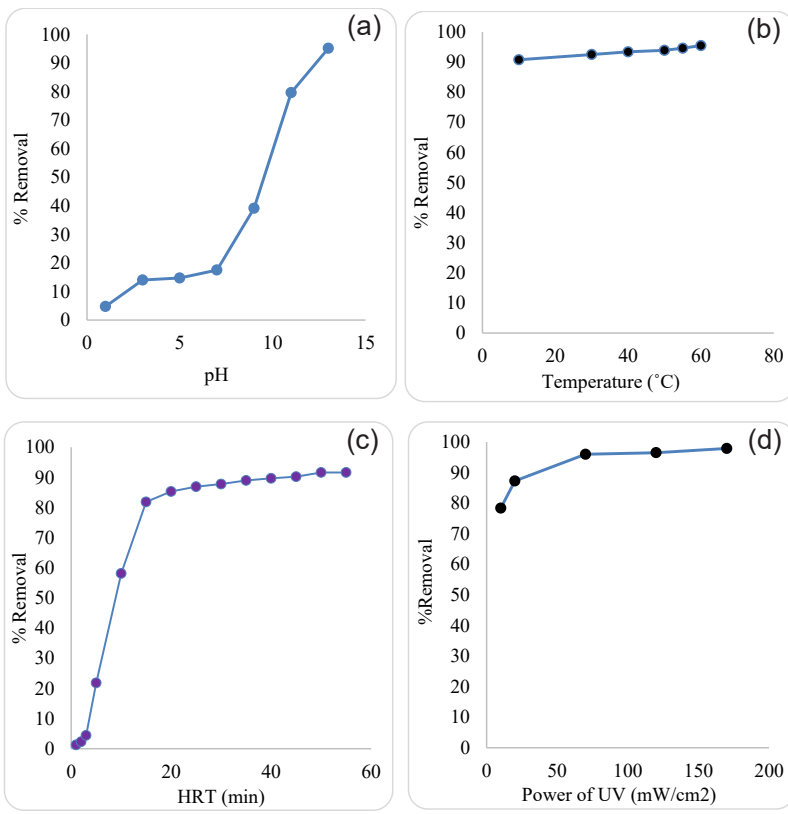

Figure 2. The effect of HRT, UV radiation power, $\mathrm{pH}$, and temperature on dye removal using UV radiation. (a) The effect of $\mathrm{pH}$ on dye removal using UV radiation at $23^{\circ} \mathrm{C}$, UV radiation of $170 \mathrm{~mW} / \mathrm{cm}^{2}$, and HRT of $15 \mathrm{~min}$. (b) The effect of temperature on dye removal efficiency using UV radiation at $\mathrm{pH} 13$, UV radiation of $170 \mathrm{~mW} / \mathrm{cm}^{2}$, and HRT of $50 \mathrm{~min}$. (c) The effect of HRT on dye removal using UV radiation at $23^{\circ} \mathrm{C}, \mathrm{pH} 13$, and UV radiation of $170 \mathrm{~mW} / \mathrm{cm}^{2}$. (d) The effect of UV radiation power on dye removal efficiency using $U V$ radiation at $50^{\circ} \mathrm{C}, \mathrm{pH} 13$, and HRT of $50 \mathrm{~min}$.
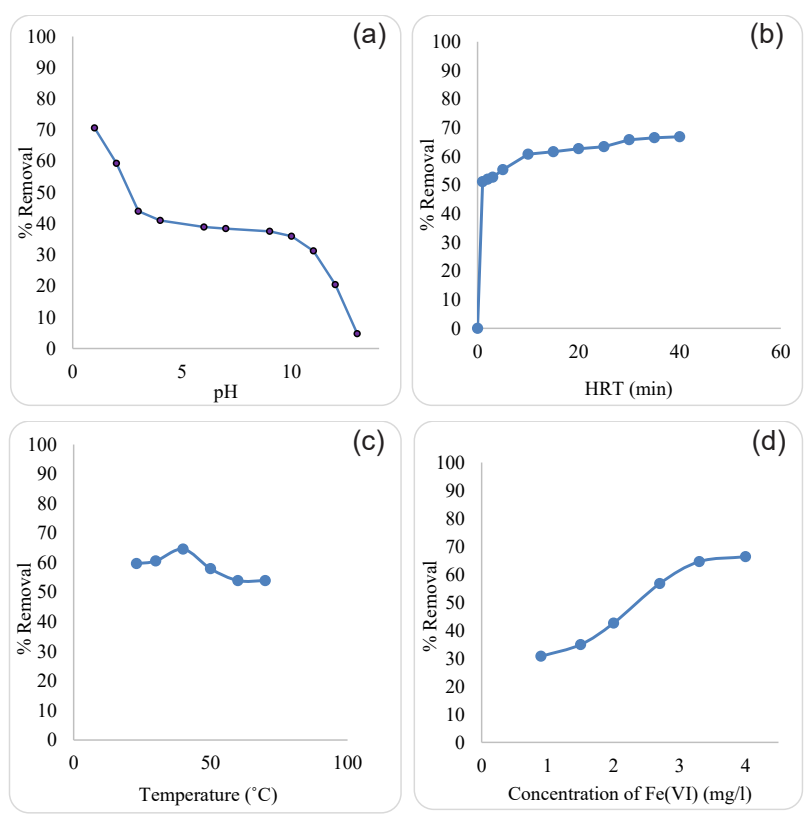

(c)

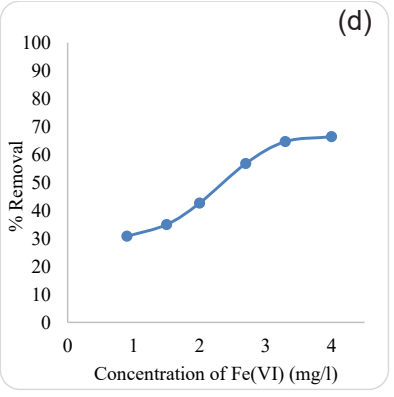

Figure 3. The effect of different factors on dye removal using $\mathrm{Fe}(\mathrm{VI})$ oxidation process. (a) The effect of $\mathrm{pH}$ on dye removal using $\mathrm{Fe}(\mathrm{VI})$ at $23^{\circ} \mathrm{C}$, HRT of $15 \mathrm{~min}$, and $\mathrm{Fe}(\mathrm{VI})$ concentration of $3.3 \mathrm{mg} / \mathrm{L}$. (b) The effect of HRT on dye removal using $\mathrm{Fe}(\mathrm{VI})$ at $23^{\circ} \mathrm{C}, \mathrm{pH}$ of 1 , and $\mathrm{Fe}(\mathrm{VI})$ concentration of $3.3 \mathrm{mg} / \mathrm{L}$. (c) The effect of temperature on dye removal using $\mathrm{Fe}(\mathrm{VI})$ at $\mathrm{pH}$ of $1, \mathrm{HRT}$ of $10 \mathrm{~min}$, and $\mathrm{Fe}(\mathrm{VI})$ concentration of $3.3 \mathrm{mg} / \mathrm{L}$. (d) The effect of $\mathrm{Fe}(\mathrm{VI})$ concentration on dye removal using $\mathrm{Fe}(\mathrm{VI})$ oxidation process at $40^{\circ} \mathrm{C}$, HRT of $10 \mathrm{~min}$, and $\mathrm{pH}$ of 1.

within the first few seconds, therefore, HRT was not considered as an effective factor in the dye removal by $\mathrm{Fe}(\mathrm{VI})$ (Figure 3b). Although some researchers reported that the reaction between $\mathrm{Fe}(\mathrm{VI})$ and some special dye is rapid (2), but others reported that pollutants removal using $\mathrm{Fe}(\mathrm{VI})$ needs a long HRT to be completed (10). Therefore, further studies on the effect of HRT on various pollutants oxidation by $\mathrm{Fe}(\mathrm{VI})$ are required. Temperatures between $23^{\circ} \mathrm{C}$ and $30^{\circ} \mathrm{C}$ were not effective in the dye removal using $\mathrm{Fe}(\mathrm{VI})$. The maximum dye removal of $65 \%$ was obtained at $40^{\circ} \mathrm{C}$. Temperature more than $40^{\circ} \mathrm{C}$ reduced the dye removal (Figure 3c). The increase of Fe(VI) concentration up to $3.3 \mathrm{mg} / \mathrm{L}$ had a positive effect on the dye removal (Figure 3d). Similar results about the effect of temperature on pollutants removal using $\mathrm{Fe}(\mathrm{VI})$ have been reported $(2,32,39,41)$.

\section{$\mathrm{ZnO}$ nanoparticles}

In this study, SEM was used to determine the size of nanoparticles. The results showed that the size of $\mathrm{ZnO}$ nanoparticles was between 27 and $58 \mathrm{~nm}$ (Figure 4). Also, the results of $\mathrm{X}-\mathrm{RD}$ test for $\mathrm{ZnO}$ nanoparticles are presented in Figure 5. The results of BET test revealed that the specific surface area of purchased $\mathrm{ZnO}$ nanoparticles was about $13 \mathrm{~m}^{2} / \mathrm{g}$. The effect of temperature, HRT, $\mathrm{pH}$, and concentration of $\mathrm{ZnO}$ nanoparticles on the dye removal using $\mathrm{ZnO}$ nanoparticles is shown in Figure 6. According to this figure, all mentioned factors had significant effect on the dye removal efficiency. 


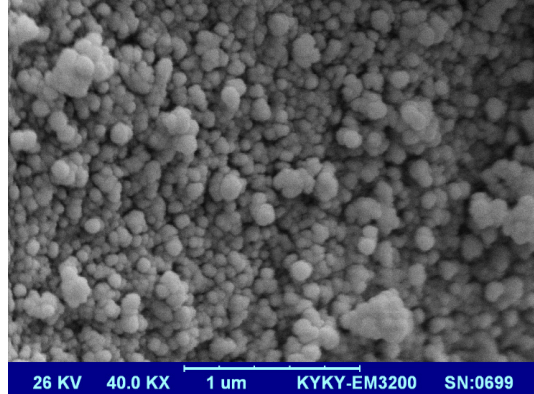

Figure 4. The SEM image of $\mathrm{ZnO}$ nanoparticles.

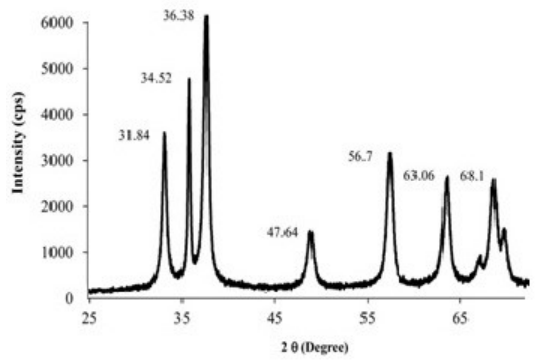

Figure 5. The results of $\mathrm{X}-\mathrm{RD}$ for $\mathrm{ZnO}$ nanoparticles.
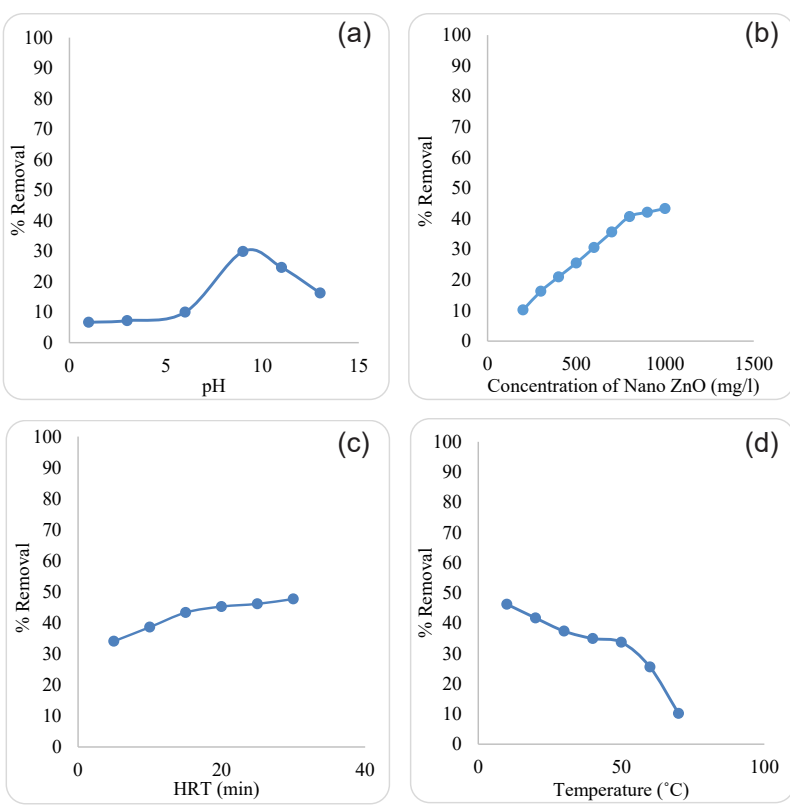

Figure 6. The effect of temperature, $\mathrm{HRT}$, $\mathrm{pH}$, and concentration of $\mathrm{ZnO}$ nanoparticles on dye removal using $\mathrm{ZnO}$ nanoparticles. (a) The effect of $\mathrm{pH}$ on dye removal efficiency using $\mathrm{ZnO}$ nanoparticles at $23^{\circ} \mathrm{C}$, HRT of $15 \mathrm{~min}$, and $\mathrm{ZnO}$ nanoparticles concentration of $200 \mathrm{mg} / \mathrm{L}$. (b) The effect of $\mathrm{ZnO}$ nanoparticles on dye removal efficiency at $23^{\circ} \mathrm{C}, \mathrm{HRT}$ of $15 \mathrm{~min}$, and $\mathrm{pH} 9$. (c) The effect of HRT on dye removal efficiency using $\mathrm{ZnO}$ nanoparticles at $23^{\circ} \mathrm{C}$, $\mathrm{pH}$ 9, and $\mathrm{ZnO}$ nanoparticles concentration of $800 \mathrm{mg} / \mathrm{L}$. (d) The effect of temperature on dye removal efficiency using $\mathrm{ZnO}$ nanoparticles at $\mathrm{pH} \mathrm{9,} \mathrm{HRT} \mathrm{of} 15 \mathrm{~min}$, and $\mathrm{ZnO}$ nanoparticles concentration of $800 \mathrm{mg} / \mathrm{L}$.

Isotherm models

Isotherm models are mathematical equations that express the equilibrium values of a substance at different concentrations that is chemically or physically absorbed on the surface of certain solid at a constant temperature.
The investigation of different isotherm models (Figure 7) showed that the absorption of dye on $\mathrm{ZnO}$ nanoparticles could be described by Langmuir isotherm $\left(\mathrm{R}^{2}=0.89\right)$. The constant coefficients of these models are also shown in Table 2. As shown in this table, the maximum adsorption capacity calculated using Jovanovic, D-R, and Langmuir is $14.05,22.29$, and $26.59 \mathrm{mg} / \mathrm{g}$, respectively. Since the results of this study showed that the adsorption of dye can be described by Langmuir isotherm, the real maximum capacity of $\mathrm{ZnO}$ nanoparticles is $26.59 \mathrm{mg} / \mathrm{g}$ (Table 2). Honorio et al reported that the maximum adsorption capacity of $57.473 \mathrm{mg} / \mathrm{g}$ could be obtained for Reactive Blue dye when soybean hulls was used as adsorbent (42). This report revealed that many other cheap and accessible adsorbents can be used instead of $\mathrm{ZnO}$ nanoparticles with the same and even more removal efficiency.

Combination of $\mathrm{ZnO}$ nanoparticles and UV radiation One of the aims of this study was to evaluate the combination of different methods to remove dye from water. In this section of study, combination of $\mathrm{ZnO}$ nanoparticles with UV radiation was investigated. The
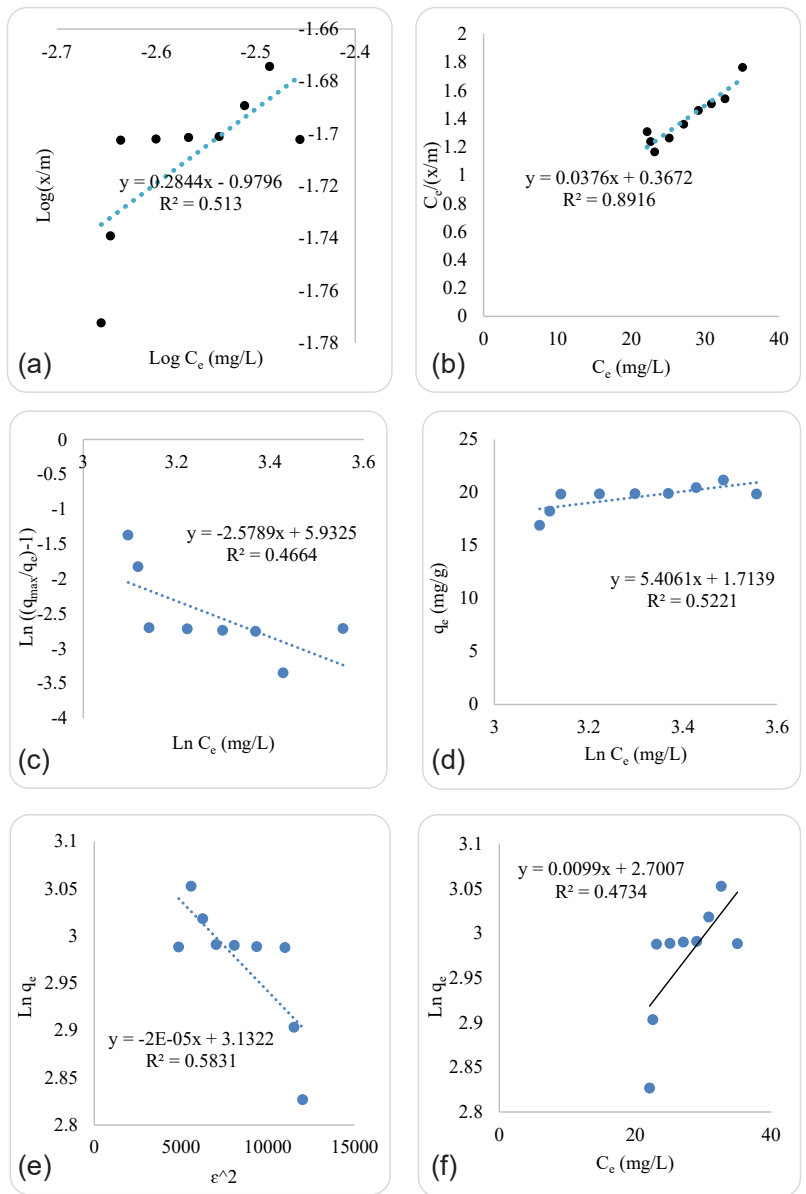

Figure 7. The regression results of Langmuir, Freundlich, Generalized, $\mathrm{D}-\mathrm{R}$, Temkin, and Jovanovic isotherm models. (a) Freundlich. (b) Langmuir. (c) Generalized. (d) Temkin. (e) D-R. (f) Jovanovic. 
Table 2. Constant coefficients of Langmuir, Freundlich, Generalized, D-R, Temkin, and Jovanovic isotherm models

\begin{tabular}{|c|c|c|c|c|c|c|c|c|c|c|c|c|c|c|c|c|c|}
\hline \multicolumn{3}{|c|}{ Jovanovic } & \multicolumn{3}{|c|}{ Generalized } & \multicolumn{3}{|l|}{ D-R } & \multicolumn{3}{|c|}{ Temkin } & \multicolumn{3}{|c|}{ Freundlich } & \multicolumn{3}{|c|}{ Langmuir } \\
\hline $\mathbf{q}_{\max }$ & $k_{j}$ & $\mathbf{R}^{2}$ & $\mathbf{N}$ & $k_{G}$ & $\mathbf{R}^{2}$ & $q_{e}$ & B & $R^{2}$ & $\mathrm{~K}_{\mathrm{T}}$ & $\mathrm{B}_{1}$ & $\mathbf{R}^{2}$ & $k_{f}$ & $n$ & $\mathbf{R}^{2}$ & $\begin{array}{l}\mathrm{a}\left(\mathrm{q}_{\max }\right. \\
(\mathrm{mg} / \mathrm{g}))\end{array}$ & $\begin{array}{l}\mathrm{b}\left(\mathrm{K}_{\mathrm{L}}(\mathrm{L} /\right. \\
\mathrm{mg}))\end{array}$ & $\mathbf{R}^{2}$ \\
\hline 14.05 & 0.0099 & 0.47 & 2.57 & 377.09 & 0.46 & 22.92 & $2 \mathrm{E}-05$ & 0.58 & 1.37 & 5.40 & 0.52 & 0.10 & 3.51 & 0.51 & 26.59 & 0.102 & 0.89 \\
\hline
\end{tabular}

results are shown in Figures 8 and 9. Since, the effect of nanoparticles concentration was investigated in several different studies (43), therefore, it was not considered in this study.

Combination of UV radiation and $\mathrm{Fe}(\mathrm{VI})$

The effect of temperature, $\mathrm{pH}$, and HRT on dye removal efficiency using combination of UV radiation and $\mathrm{Fe}(\mathrm{VI})$ oxidation process is illustrated in Figure 8. The results demonstrated the dye removal efficiency using this combined method at $\mathrm{pH}$ values between 2 and 13 was higher than $\mathrm{pH} 9$ (Figure 10a). In this section of study, the effect of temperature $\left(30\right.$ to $\left.60^{\circ} \mathrm{C}\right)$ on the combination of $\mathrm{UV}$ radiation and $\mathrm{Fe}(\mathrm{VI})$ was investigated. Increasing temperature had a somewhat negative effect on the dye
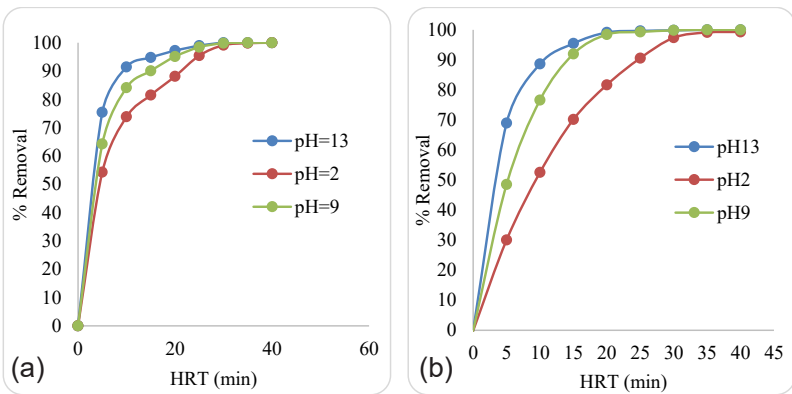

Figure 8. The effects of $\mathrm{pH}, \mathrm{HRT}$, and UV power on dye removal efficiency using combination of $\mathrm{ZnO}$ nanoparticles and UV radiation. (a) The effects of $\mathrm{pH}$ and HRT on dye removal efficiency using combination of $\mathrm{ZnO}$ nanoparticles and $\mathrm{UV}$ radiation at $23^{\circ} \mathrm{C}$, UV power of $70 \mathrm{~mW} / \mathrm{cm}^{2}$, and $\mathrm{ZnO}$ nanoparticles concentration of $800 \mathrm{mg} / \mathrm{L}$. (b) The effects of $\mathrm{pH}$ and HRT on dye removal efficiency using combination of $\mathrm{ZnO}$ nanoparticles and UV radiation at $23^{\circ} \mathrm{C}$, UV power of $170 \mathrm{~mW} / \mathrm{cm}^{2}$, and $\mathrm{ZnO}$ nanoparticles concentration of $800 \mathrm{mg} / \mathrm{L}$.

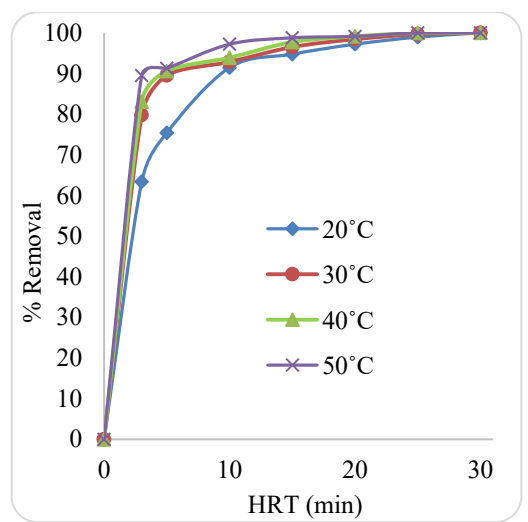

Figure 9. Effect of HRT and temperature on dye removal using combination of $\mathrm{ZnO}$ nanoparticles and $\mathrm{UV}$ radiation $\left(70 \mathrm{~mW} / \mathrm{cm}^{2}\right)$. removal using combined methods (Figure 10b).

Combination of $\mathrm{ZnO}$ nanoparticles and $\mathrm{Fe}(\mathrm{VI})$ oxidation process

The effect of $\mathrm{pH}$, temperature, and HRT on dye removal using combination of $\mathrm{ZnO}$ nanoparticles and $\mathrm{Fe}(\mathrm{VI})$ oxidation process was investigated in this part of the study. The effect of $\mathrm{pH}$ between 2 and 13 is shown in Figure 11a. The results of evaluation of the effect of temperature on the dye removal efficiency using combination of $\mathrm{ZnO}$ nanoparticles and the $\mathrm{Fe}(\mathrm{VI})$ oxidation process are shown in Figure 11b.

\section{Discussion}

UV radiation

UV radiation is a powerful beam that can decompose various chemical compounds. In this study, direct UV was radiated to the surface of water contaminated with dye. The results showed that four factors of temperature, $\mathrm{pH}, \mathrm{HRT}$, and UV radiation power were effective in removing dye from contaminated water exposed to the $\mathrm{UV}$ radiation. $\mathrm{pH}$ is a factor affecting the efficiency of chemical and photochemical reactions. This study showed that increased $\mathrm{pH}$ values could increase the dye removal efficiency by UV radiation (Figure $2 \mathrm{a}$ ). At $\mathrm{pH} 1$, only $5 \%$ of the dye was removed from the water. By increasing $\mathrm{pH}$ to 7 , the dye removal efficiency reached $17 \%$. By changing the conditions from neutral to alkaline, the dye removal efficiency was increased sharply. At $\mathrm{pH}$ values of 9,11 , and 13 , the dye removal efficiency was $39 \%, 80 \%$, and
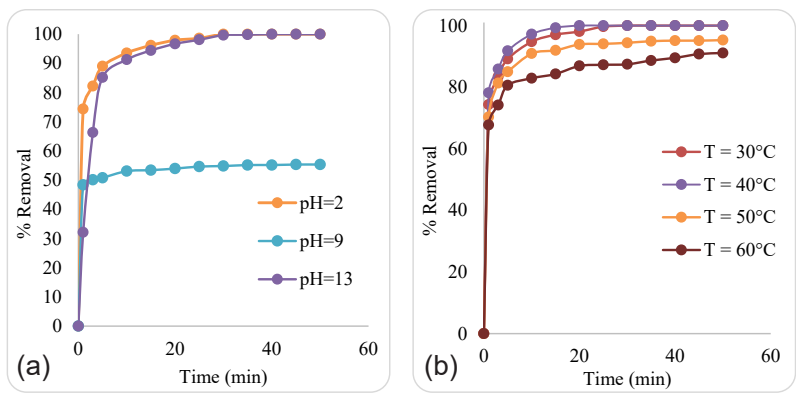

Figure 10. Effect of temperature, $\mathrm{pH}$, and $\mathrm{HRT}$ on dye removal efficiency using combination of UV radiation and $\mathrm{Fe}(\mathrm{VI})$ oxidation process. (a) The effect of HRT on dye removal efficiency using combination of UV radiation and $\mathrm{Fe}(\mathrm{VI})$ oxidation process at different $\mathrm{pHs}, 23^{\circ} \mathrm{C}, \mathrm{Fe}(\mathrm{VI})$ concentration of $3.3 \mathrm{mg} / \mathrm{L}$, and UV radiation power of $170 \mathrm{~mW} / \mathrm{cm}^{2}$. (b) The effect of HRT on dye removal efficiency using combination of UV radiation and $\mathrm{Fe}(\mathrm{VI})$ oxidation process at various temperatures, $\mathrm{pH} 2, \mathrm{Fe}(\mathrm{VI})$ concentration of $3.3 \mathrm{mg} / \mathrm{L}$, and UV radiation power of $170 \mathrm{~mW} / \mathrm{cm}^{2}$. 

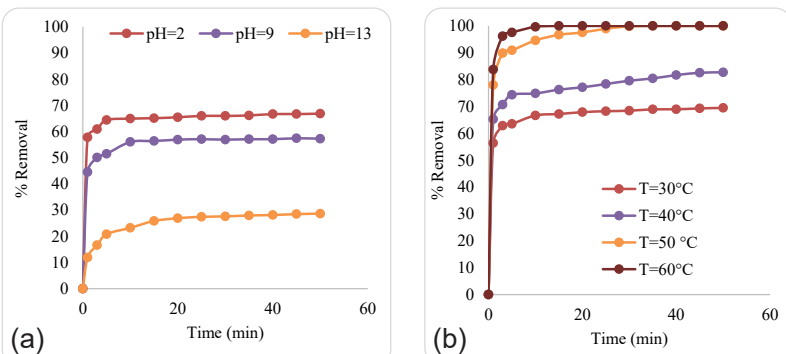

Figure 11. The effect of temperature, $\mathrm{pH}$, and HRT on dye removal efficiency using combination of $\mathrm{ZnO}$ nanoparticles and $\mathrm{Fe}(\mathrm{VI})$ oxidation process. (a) The effect of $\mathrm{pH}$ and HRT on dye removal efficency using combination of $\mathrm{ZnO}$ nanoparticles and $\mathrm{Fe}(\mathrm{VI})$ oxidation process at $23^{\circ} \mathrm{C}$, $\mathrm{Fe}(\mathrm{VI})$ concentration of $3.3 \mathrm{mg} / \mathrm{L}$, and $\mathrm{ZnO}$ nanoparticles concentration of $800 \mathrm{mg} / \mathrm{L}$. (b) The effect of temperature and HRT on dye removal efficiency using combination of $\mathrm{ZnO}$ nanoparticles and $\mathrm{Fe}(\mathrm{VI})$ oxidation process at $\mathrm{pH}$ 2, $\mathrm{Fe}(\mathrm{VI})$ concentration of $3.3 \mathrm{mg} / \mathrm{L}$, and $\mathrm{ZnO}$ nanoparticles concentration of $800 \mathrm{mg} / \mathrm{L}$.

95\%, respectively. According to Figure 2a, UV can remove the dye due to the production of free electron or free radical on the dye molecule. So, a negative charge will be produced on the dye molecules. In acidic ambient $(\mathrm{pH}<4)$, the breakdown of dye molecule is not possible due to the absorption of UV photons by the high concentration of $\mathrm{H}_{3} \mathrm{O}^{+}$cations. As shown in Figure 2a, the dye removal by $\mathrm{UV}$ radiation was enhanced by increased $\mathrm{pH}$ of solution, increased $\mathrm{OH}^{-}$concentration, and decreased $\mathrm{H}_{3} \mathrm{O}^{+}$ disturbance.

Figure $2 \mathrm{~b}$ illustrates that the efficiency of UV to remove dye was increased at higher temperatures. So, the increase of entropy of system and the number of collision to achieve equilibrium is the main reason to enhance the UV efficiency. It was revealed that $87 \%$ of the dye was removed in the first 20 minutes of the reaction in the presence of UV (Figure 2c). As mentioned above and shown in Figure 2d, the UV radiation can remove dye with a high efficiency. The UV has been used to remove different pollutants. Talaiekhozani et al reported that nearly $100 \%$ of formaldehyde was removed from water using UV radiation (38). Such reports show that the UV radiation can be efficiently used for the removal of a wide variety of chemicals.

\section{$\mathrm{Fe}(\mathrm{VI})$}

$\mathrm{pH}$ is one of the most important parameters affecting oxidation reactions. The effect of $\mathrm{pH}$ variations on the dye removal efficiency is shown in Figure 3a. As can be seen, by increasing $\mathrm{pH}$ from 1 to 13 , the dye removal efficiency decreased sharply from $71 \%$ to $5 \%$. The dye removal efficiency was constant at $\mathrm{pH}$ values between 3 and 9. By increasing $\mathrm{pH}$ from 9 to 13 , the dye removal efficiency was significantly reduced. It implies that in acidic environments, the rate of removal process is higher. This fact can be explained by examining the rate of ferrate(VI) degradation. $\mathrm{Fe}(\mathrm{VI})$ is generated using electrolysis process based on equation 9 .

$$
\text { Iron electrode } \stackrel{\text { Electrolysis }+\mathrm{NaOH}}{\longrightarrow} \mathrm{Fe}(\mathrm{VI})
$$

The color of electrolyte is changed to purple when Fe(VI) is generated. There are two important forms of $\mathrm{Fe}(\mathrm{VI})$ : $\mathrm{FeO}_{4}^{-2}$ and $\mathrm{HFeO}_{4}^{-}$. The rate of $\mathrm{Fe}(\mathrm{VI})$ consumption can be calculated using equation 10 :

$\mathrm{K}(\mathrm{Fe}(\mathrm{VI}))=\mathrm{K}_{1}\left(\mathrm{HFeO}_{4}^{-}\right)+\mathrm{K}_{2}\left(\mathrm{FeO}_{4}^{2-}\right)$

Comparison of constant consumption rates of $\mathrm{HFeO}_{4}^{-}$ $\left(\mathrm{K}_{1}=1.24 \times 10^{7} \mathrm{M} / \mathrm{S}\right)$ and $\mathrm{FeO}_{4}^{2-}\left(\mathrm{K}_{2}=8.41 \times 10^{2} \mathrm{M} / \mathrm{S}\right)$ shows that $\mathrm{HFeO}_{4}^{-}$is dominant. Consequently, the reaction rate of $\mathrm{HFeO}_{4}^{-}$and dye was higher than that of $\mathrm{FeO}_{4}^{2-}$ (16). Therefore, $\mathrm{HFeO}_{4}^{-}$has a key role in the removal of dye compared with $\mathrm{FeO}_{4}^{2-}$. Under acidic condition, the dominant species of $\mathrm{Fe}(\mathrm{VI})$ is $\mathrm{HFeO}_{4}^{-}$and under basic conditions, $\mathrm{Fe}(\mathrm{VI})$ is mainly appeared in the form of $\mathrm{FeO}_{4}{ }^{2-}$. Since $\mathrm{HFeO}_{4}{ }^{-}$is more effective than $\mathrm{FeO}_{4}{ }^{2-}, \mathrm{Fe}(\mathrm{VI})$ is much more effective in acidic condition.

HRT is an important parameter in determining the size of chemical reactors. The effect of HRT changes on dye removal is shown in Figure 3b. As can be seen, the reaction between $\mathrm{Fe}(\mathrm{VI})$ and the dye was rapid. A rapid reaction means that it can be performed in a very short HRT. One of the advantages of rapid reaction is that to remove dye, a very small reactor is needed that reduces costs. Talaiekhozani et al reported that changes in HRT did not have any significant effect on $\mathrm{Fe}(\mathrm{VI})$ removal efficiency (32).

Temperature is a parameter that influences the oxidation reactions. Figure $3 \mathrm{c}$ shows the effect of temperature on the dye removal efficiency. As shown in this figure, the increase of temperature from $23^{\circ} \mathrm{C}$ to $40^{\circ} \mathrm{C}$ has a positive effect on the dye removal efficiency using $\mathrm{Fe}(\mathrm{VI})$. The results of this study showed that temperatures above $40^{\circ} \mathrm{C}$ had a negative effect on the removal of dye from the water using $\mathrm{Fe}(\mathrm{VI})$, which is consistent with the results of the study by Eskandari (10). She investigated the effect of temperature on the conversion rate of $\mathrm{Fe}(\mathrm{VI})$ to $\mathrm{Fe}(\mathrm{III})$. She reported that $\mathrm{Fe}(\mathrm{VI})$ is gradually converted to $\mathrm{Fe}(\mathrm{III})$ based on the equation 11 (10):

$4 \mathrm{Na}_{2} \mathrm{FeO}_{4}+10 \mathrm{H}_{2} 0 \rightarrow 8 \mathrm{NaH}+4 \mathrm{Fe}(\mathrm{OH})_{3}+3 \mathrm{O}_{2} \uparrow$

Eskandari demonstrated that the conversion rate of $\mathrm{Fe}(\mathrm{VI})$ to $\mathrm{Fe}(\mathrm{III})$ at temperatures between 20 and $50^{\circ} \mathrm{C}$ does not have a significant variation. When temperature increases to more than $50^{\circ} \mathrm{C}$, the conversion rate of $\mathrm{Fe}(\mathrm{VI})$ to $\mathrm{Fe}$ (III) also raises, therefore, the concentration of $\mathrm{Fe}(\mathrm{VI})$ in the solution declines. $\mathrm{Fe}(\mathrm{III})$ is a strong coagulant but it cannot be used as an oxidant for the removal of organic compounds (9). It means that the ability of $\mathrm{Fe}(\mathrm{VI})$ oxidation is decreased at temperatures above $50^{\circ} \mathrm{C}$. There are two known ways for degradation of the $\mathrm{Fe}(\mathrm{VI})$ : (a) self-degradation and (b) reactions with organic 
compounds. Talaiekhozani et al provided an empirical equation to predict the removal efficiency of dye in various environmental conditions including temperature, $\mathrm{pH}$, and HRT when $\mathrm{Fe}(\mathrm{VI})$ is used (2). Although this empirical equation is specifically designed to remove 1,9-DimethylMethylene Blue zinc chloride double salt, it can also be used to predict the suppression of other dyes by $\mathrm{Fe}(\mathrm{VI})$. One of the important parameters in controlling the dye removal is concentration of $\mathrm{Fe}(\mathrm{VI})$. In this study, the effect of initial concentration of $\mathrm{Fe}(\mathrm{VI})$ on the dye removal efficiency was investigated (Figure 3d). The results showed that by increasing the concentration of $\mathrm{Fe}(\mathrm{VI})$ from 0.9 to $3.3 \mathrm{mg} / \mathrm{L}$, the dye removal efficiency increased. However, at a concentration more than $3.3 \mathrm{mg} / \mathrm{L}$, no change in the efficiency was observed. In this study, it was found that the best ratio of dye to $\mathrm{Fe}(\mathrm{VI})$ is 11.81 . Han et al reported that $97.5 \%$ bisphenol A (BPA) removal was achieved when $\mathrm{Fe}(\mathrm{VI})$ oxidation process was used (44). Such studies illustrate that $\mathrm{Fe}(\mathrm{VI})$ oxidation process can be applied for a wide range of chemicals specially for recalcitrant compounds. Zhou and Jiang revealed that Fe(VI) had a much higher reactivity with ciprofloxacin than ibuprofen (45), therefore, it can be concluded that the reaction of $\mathrm{Fe}(\mathrm{VI})$ with all chemicals is not the same. The results of this study showed that $\mathrm{Fe}(\mathrm{VI})$ oxidation is not an appropriate process for Reactive Blue 203 dye since only $71 \%$ of the dye is removed under optimum condition.

\section{$\mathrm{ZnO}$ nanoparticles}

Figure $4 \mathrm{a}$ shows that increasing the concentration of nanoparticles between 0.02 and $800 \mathrm{mg} / \mathrm{L}$, leads to a linear increase in the removal efficiency of the dye. However, the rate of dye removal decreased when the concentration of nanoparticles increased to more than $800 \mathrm{mg} / \mathrm{L}$. The results showed that using $200 \mathrm{mg} / \mathrm{L}$ of $\mathrm{ZnO}$ nanoparticle, only $10 \%$ of the dye was removed. Also, $41 \%$ of the dye was removed when the concentration of $\mathrm{ZnO}$ nanoparticles was $800 \mathrm{mg} / \mathrm{L}$. Increasing the concentration of nanoparticles from 800 to $100 \mathrm{mg} / \mathrm{L}$, resulted in only a $2 \%$ increase in the dye removal efficiency.

The amount of dye removal was increased by changing $\mathrm{pH}$ from acidic to alkaline. The dye removal was reduced at $\mathrm{pH}$ 11. It means that the effect of the $\mathrm{ZnO}$ nanoparticles decreased at a $\mathrm{pH}$ higher than 10 (Figure $4 \mathrm{~b}$ ). It can be due to this fact that the dye has a negative charge in alkaline solution and is repulsed by negative adsorber surface at $\mathrm{pH}$ values higher than 9. It is obvious that the concentration of $\mathrm{OH}^{-}$will be saturated at a $\mathrm{pH}$ near to 14 and causes a disturbance on the surface of adsorber to prevent the adsorption of dye by $\mathrm{ZnO}$. So, the dye removal decrease at $\mathrm{pHs}$ higher than 11. As shown in Figures $5 \mathrm{c}$ and $5 \mathrm{~d}$, with an increase in temperature, the efficiency of dye removal was reduced which is against the mechanism of the effect of increase of temperature and increase of entropy on adsorption. The reason of these phenomena can be explained according to the effect of an increase in temperature on the structure of $\mathrm{ZnO}$ adsorber. The volume of pores and total volume of $\mathrm{ZnO}$ decrease by an increase in temperature due to empty space of ionized oxygen in the $\mathrm{ZnO}$ structure and electron transfer among stimulated pores. By increasing the volume, it can be expected that the surface of adsorption and the adsorption efficiency are decreased (46-49).

\section{Combination of $\mathrm{ZnO}$ nanoparticles and $\mathrm{UV}$ radiation}

One of the aims of this study was to evaluate the combination of different methods to remove dye from water. In this section of the study, combination of $\mathrm{ZnO}$ nanoparticles with UV radiation was investigated. The results showed that HRT had a major effect on the removal of dye when a combination of $\mathrm{ZnO}$ nanoparticles and $\mathrm{UV}$ radiation was used. The results showed that at a $\mathrm{pH}$ more than 9, the UV radiation power of $170 \mathrm{~mW} / \mathrm{cm}^{2}$, and HRT of 20 minutes approximately $98 \%$ of the dye was removed. Increasing HRT to more than 20 minutes did not increase the dye removal efficiency. The results demonstrated that $\mathrm{pH}$ has a key role in this process. As shown in Figure 8a, an increase in $\mathrm{pH}$ from 2 to 13 leads to an increase in the dye removal efficiency. At $\mathrm{pH}$ 2, an HRT more than 30 minutes was required to remove $98 \%$ of the dye. The effect of intensity of UV radiation on the removal efficiency of dye was also investigated in this study. The amount of UV radiation in Figures $8 \mathrm{a}$ and $\mathrm{b}$ was 170 and $70 \mathrm{~mW} / \mathrm{cm}^{2}$, respectively. The required HRT to remove $98 \%$ of the dye at $\mathrm{pH} 9$ under $\mathrm{UV}$ radiation with power of $70 \mathrm{~mW} / \mathrm{cm}^{2}$, was 25 minutes. (i.e., 5 minutes more than that required for $\mathrm{UV}$ radiation of $170 \mathrm{~mW} / \mathrm{cm}^{2}$ ). Further studies are needed to understand whether increasing UV radiation power is economic or increasing HRT.

In this study, temperature was also investigated and it was found that the removal efficiency of dye using combination of $\mathrm{ZnO}$ nanoparticles and UV radiation had a higher performance at higher temperatures. However, at temperatures above $20^{\circ} \mathrm{C}$, the dye removal efficiency was very close to each other (Figure 9). The results of this study showed that at $50^{\circ} \mathrm{C}$, only $98 \%$ of the dye can be removed in the HRT of 10 minutes. Further studies are required to understand increasing temperature is economic to remove dye using combination of $\mathrm{ZnO}$ nanoparticles and UV radiation or increasing HRT. The results showed that under UV radiation, the reaction of $\mathrm{ZnO}$ nanoparticles to temperature was changed. The increase in temperature has a detrimental effect on the dye removal efficiency when $\mathrm{ZnO}$ nanoparticles alone were used. Also, temperature was not recognized as an effective factor when UV radiation alone was used. The results revealed that when $\mathrm{ZnO}$ nanoparticles used under UV radiation, the temperature became an effective factor on dye removal.

The $\mathrm{ZnO}$ nanoparticles that draw the researchers' 
attentions as a good semiconductor in the presence of UV radiation to remove pollutants from wastewater, act as a catalyst and adsorb high energized photon. So, the hydroxyl group will be produced by the nanoparticles in the presence of UV radiation. When nanoparticles adsorb photon containing energy higher than the energy gap of nanoparticle structure, it can lead to transfer of electron from the valence band to conduction band. If the separation of electrical charge happens, electron will transfer to the surface of catalyst and takes part in the reduction-oxidation reactions.

Temperature acts as an important parameter that can affect the photocatalytic adsorption. The increase of temperature makes the transfer of electrons to the surface of catalyst to be higher and the production of pore-electron to be easier. These electrons and pores themselves, are able to degrade the organic pollutants and increase the efficiency of photocatalytic pollutants removal (50). Shahrezaei et al stated that temperature was the most effective parameter on the efficiency of photocatalytic pollutants removal (50). They also stated that the optimum temperature to remove organic oil refinery pollutants was $45^{\circ} \mathrm{C}$ and the concentration of catalyst was $100 \mathrm{mg} / \mathrm{L}$.

Combination of UV radiation and $\mathrm{Fe}(\mathrm{VI})$

In this section of study, the combination of UV radiation and $\mathrm{Fe}(\mathrm{VI})$ oxidation process was investigated. The results showed that the increase in temperature up to $40^{\circ} \mathrm{C}$ had a positive effect and more than $40^{\circ} \mathrm{C}$ had a negative effect on dye removal efficiency using combination of UV radiation and $\mathrm{Fe}(\mathrm{VI})$ oxidation process (Figure $10 \mathrm{~b}$ ). The reason of this phenomenon was previously explained in the section of dye removal using $\mathrm{Fe}(\mathrm{VI})$ oxidation process alone. Also, the effect of $\mathrm{pH}$ on the dye removal efficiency showed that the highest dye removal efficiency was obtained at two $\mathrm{pHs}$ of 2 and 13 (Figure 10a). The results illustrated that the HRT between 0 and 10 minutes has a significant effect on the removal efficiency, but by increasing the HRT to more than 10 minutes, this effect became less significant. At $40^{\circ} \mathrm{C}, \mathrm{pH} 2, \mathrm{Fe}(\mathrm{VI})$ concentration of $3.3 \mathrm{mg} / \mathrm{L}$, and the UV radiation power of $170 \mathrm{~mW} / \mathrm{cm}^{2}$, nearly $99 \%$ of the dye was removed in $15 \mathrm{~min}$. However, the dye removal efficiency was not higher than $53 \%$ under the same condition at $\mathrm{pH}$ 9. Apparently, further studies are recommended to identify the reasons for such a behavior in the removal of dye using the combination of $\mathrm{UV}$ radiation and $\mathrm{Fe}(\mathrm{VI})$ oxidation process. Talaiekhozani et al reported that $65 \%$ and $73 \%$ of hydrogen sulfide and chemical oxygen demand (COD) were removed, respectively, when the combination of UV radiation and $\mathrm{Fe}(\mathrm{VI})$ was used (39). It seems that this method is more effective in the removal of dye compared with that of hydrogen sulfide and COD.

Combination of $\mathrm{ZnO}$ nanoparticles and $\mathrm{Fe}(\mathrm{VI})$ oxidation process

In this part of the study, the effect of $\mathrm{pH}$ and HRT on the removal of dye using the combination of $\mathrm{ZnO}$ nanoparticles and the $\mathrm{Fe}(\mathrm{VI})$ oxidation process was investigated. The effect of $\mathrm{pH}$ between 2 and 13 is shown in Figure 11a. The $\mathrm{pH}$ reduction results in an increase in the removal efficiency of the dye. The maximum dye removal efficiency at $\mathrm{pH} 13$ and HRT of 50 minutes was $28 \%$. The maximum dye removal efficiency at HRT of 50 minutes was $57 \%$ when $\mathrm{pH} 9$ was achieved. At $\mathrm{pH}$ of 2 and HRT of 50 minutes, the maximum removal efficiency was $67 \%$. The optimum HRT was also different at various $\mathrm{pH}$ levels. For example, at $\mathrm{pH}$ values of 13,9 , and 2 , the optimum HRT value was 20,10 , and 5 minutes, respectively.

The results of evaluation of the temperature effect on the dye removal efficiency using the combination of $\mathrm{ZnO}$ nanoparticles and the $\mathrm{Fe}(\mathrm{VI})$ oxidation process are shown in Figure 9b. The temperature increase had a positive effect on the dye removal efficiency using combination of $\mathrm{ZnO}$ nanoparticles and the $\mathrm{Fe}(\mathrm{VI})$ oxidation process. Increasing the temperature from 30 to $60^{\circ} \mathrm{C}$ led to an increase in the dye removal efficiency from $69 \%$ to nearly $100 \%$. Honorio et al showed that $96 \%$ of the Reactive Blue 203 dye was removed from water using advance oxidation process (AOP) (42). Comparing these results with the results of this study revealed that combination of $\mathrm{ZnO}$ nanoparticles and $\mathrm{Fe}(\mathrm{VI})$ oxidation process may work better than the AOP.

\section{Conclusion}

In this study, the effective factors on the removal efficiency of Reactive Blue 203 using UV radiation, Fe(VI) oxidation process, absorption by $\mathrm{ZnO}$ nanoparticles, the combination of $\mathrm{ZnO}$ nanoparticles and $\mathrm{Fe}(\mathrm{VI})$ oxidation process, UV radiation and $\mathrm{ZnO}$ nanoparticles, and the composition UV radiation and $\mathrm{Fe}(\mathrm{VI})$ oxidation process were investigated. Also, the removal mechanism for some of the above-mentioned methods was presented. Removal of Reactive Blue 203 using Fe(VI) oxidation process can be completed during a fraction of seconds; therefore, it can be categorized as a rapid reaction. UV radiation, $\mathrm{Fe}(\mathrm{VI})$ oxidation process, and $\mathrm{ZnO}$ nanoparticles were able to remove $97 \%, 71 \%$, and $47 \%$ of the dye under optimal conditions, respectively. Also, $100 \%$ of the dye was removed when the combination of $\mathrm{Fe}(\mathrm{VI})$ oxidation process and UV radiation was used under optimum conditions. Combination of $\mathrm{ZnO}$ nanoparticles and $\mathrm{Fe}(\mathrm{VI})$ oxidation process was also able to remove nearly $100 \%$ of the dye. Using the combination of $\mathrm{ZnO}$ nanoparticles and UV radiation under optimal conditions, the removal efficiency of the dye was close to $100 \%$. All three factors including temperature, $\mathrm{pH}$, and HRT were highly effective on hybrid processes. It was also found that by combining the various methods as mentioned in this study, the effect of some factors such as $\mathrm{pH}$ and temperature varies on the removal efficiency of dye using the processes. For example, when the $\mathrm{ZnO}$ nanoparticles alone were used, the increase in temperature have a negative effect on 
the dye removal efficiency, but when the combination of $\mathrm{UV}$ radiation and $\mathrm{ZnO}$ nanoparticles was used, the temperature had a positive effect on the dye removal efficiency. Since the effect of the concentration of $\mathrm{ZnO}$ nanoparticles on the combination of $\mathrm{ZnO}$ nanoparticles and UV radiation was not investigated, it is recommended to investigate this parameter in future studies. The effect of dye concentration was not also evaluated in this study, therefore, it is recommended to investigate this parameter in future studies. Furthermore, it is recommended that the kinetics reaction of dye removal using UV radiation be evaluated in future studies.

\section{Acknowledgements}

The authors would like to appreciate Jami Institute of Technology for its logistic support, which led to the completion of this dissertation.

\section{Ethical issues}

Authors are aware of, and comply with, best practice in publication ethics specifically with regard to authorship (avoidance of guest authorship), dual submission, manipulation of figures, competing interests and compliance with policies on research ethics. Authors certify that submitted work is original and has not been published elsewhere.

\section{Competing interests}

The authors declare that there is no conflict of interests.

\section{Authors' contribution}

All authors were equally involved in the collection, analysis, and interpretation of the data. All authors critically reviewed, refined, and approved the manuscript.

\section{References}

1. Hunge YM, Mahadik MA, Patil VL, Pawar AR, Gadakh SR, Moholkar AV, et al. Visible light assisted photoelectrocatalytic degradation of sugarcane factory wastewater by sprayed CZTS thin films. J Phys Chem Solids 2017; 111: 176-81. doi: 10.1016/j.jpcs.2017.07.023.

2. Talaiekhozani A, Banisharif F, Eskandari Z, Talaiekhozani MR, Park J, Rezania S. Kinetic investigation of 1,9-dimethylmethylene blue zinc chloride double salt removal from wastewater using ferrate (VI) and ultraviolet radiation. Journal of King Saud University - Science 2018. [In Press]. doi: $10.1016 /$ j.jksus.2018.04.010.

3. Yang B, Zuo J, Tang X, Liu F, Yu X, Tang X, et al. Effective ultrasound electrochemical degradation of methylene blue wastewater using a nanocoated electrode. Ultrason Sonochem 2014; 21(4): 1310-7. doi: 10.1016/j. ultsonch.2014.01.008.

4. Liu M, Chen Q, Lu K, Huang W, Lu Z, Zhou C, et al. High efficient removal of dyes from aqueous solution through nanofiltration using diethanolamine-modified polyamide thin-film composite membrane. Sep Purif Technol 2017; 173: 135-43. doi: 10.1016/j.seppur.2016.09.023.
5. Jorfi S, Darvishi Cheshmeh Soltani R, Ahmadi M, Khataee A, Safari M. Sono-assisted adsorption of a textile dye on milk vetch-derived charcoal supported by silica nanopowder. J Environ Manage 2017; 187: 111-21. doi: 10.1016/j.jenvman.2016.11.042.

6. Pirkarami A, Olya ME. Removal of dye from industrial wastewater with an emphasis on improving economic efficiency and degradation mechanism. J Saudi Chem Soc 2017; 21: S179-86. doi: 10.1016/j.jscs.2013.12.008.

7. Ashtekar VS, Bhandari VM, Shirsath SR, Sai Chandra PL, Jolhe PD, Ghodke S. Dye wastewater treatment: Removal of reactive dyes using inorganic and organic coagulants. Journal of Industrial Pollution Control 2014; 30(1): 33-42.

8. Isarain-Chavez E, Baro MD, Rossinyol E, Morales-Ortiz $\mathrm{U}$, Sort J, Brillas E, et al. Comparative electrochemical oxidation of methyl orange azo dye using Ti/Ir-Pb, Ti/Ir-Sn, $\mathrm{Ti} / \mathrm{Ru}-\mathrm{Pb}, \mathrm{Ti} / \mathrm{Pt}-\mathrm{Pd}$ and $\mathrm{Ti} / \mathrm{RuO} 2$ anodes. Electrochim Acta 2017; 244: 199-208. doi: 10.1016/j.electacta.2017.05.101.

9. Tchobanoglous G, Burton FL, Stensel HD. Wastewater engineering: treatment and reuse. 4th ed. New York: McGraw-Hill; 2003.

10. Eskandari Z. Control of hydrogen sulfide and organic compounds in municipal wastewater by using ferrate (VI) produced by electrochemical method [dissertation]. Isfahan: Jami Institute of Tecxhnology; 2016.

11. Sharma VK. Ferrate(VI) and ferrate(V) oxidation of organic compounds: kinetics and mechanism. Coord Chem Rev 2013; 257(2): 495-510. doi: 10.1016/j.ccr.2012.04.014.

12. Talaiekhozani A, Talaei MR, Rezania S. An overview on production and application of ferrate (VI) for chemical oxidation, coagulation and disinfection of water and wastewater. J Environ Chem Eng 2017; 5(2): 1828-42. doi: 10.1016/j.jece.2017.03.025.

13. Zhou Z, Fang S, Chen H, Ji J, Wu J. Trials of treating decentralized domestic sewage from a residential area by potassium ferrate(VI). Water Air Soil Pollut 2017; 228(8): 316. doi: 10.1007/s11270-017-3457-7.

14. Sun S, Pang SY, Jiang J, Ma J, Huang Z, Zhang J, et al. The combination of ferrate(VI) and sulfite as a novel advanced oxidation process for enhanced degradation of organic contaminants. Chem Eng J 2018; 333: 11-9. doi: 10.1016/j. cej.2017.09.082.

15. Sharma VK, Liu F, Tolan S, Sohn M, Kim H, Oturan MA. Oxidation of beta-lactam antibiotics by ferrate(VI). Chem Eng J 2013; 221: 446-51. doi: 10.1016/j.cej.2013.02.024.

16. Rush JD, Bielski BH. Decay of ferrate (V) in neutral and acidic solutions. A premix pulse radiolysis study. Inorg Chem 1994; 33(24): 5499-502. doi: 10.1021/ic00102a024.

17. Rai PK, Lee J, Kailasa SK, Kwon EE, Tsang YF, Ok YS, et al. A critical review of ferrate(VI)-based remediation of soil and groundwater. Environ Res 2018; 160: 420-48. doi: 10.1016/j.envres.2017.10.016.

18. Pepino Minetti RC, Macano HR, Britch J, Allende MC. In situ chemical oxidation of BTEX and MTBE by ferrate: $\mathrm{pH}$ dependence and stability. J Hazard Mater 2017; 324(Pt B): 448-56. doi: 10.1016/j.jhazmat.2016.11.010.

19. Manoli K, Nakhla G, Ray AK, Sharma VK. Oxidation of caffeine by acid-activated ferrate(VI): effect of ions and natural organic matter. AIChE J 2017; 63(11): 4998-5006. doi: $10.1002 /$ aic. 15878 . 
20. Monfort O, Usman M, Soutrel I, Hanna K. Ferrate(VI) based chemical oxidation for the remediation of aged PCB contaminated soil: comparison with conventional oxidants and study of limiting factors. Chemical Engineering Journal 2019; 355(1): 109-17. doi: 10.1016/j.cej.2018.08.116.

21. Malik SN, Ghosh PC, Vaidya AN, Waindeskar V, Das S, Mudliar SN. Comparison of coagulation, ozone and ferrate treatment processes for color, COD and toxicity removal from complex textile wastewater. Water Sci Technol 2017; 76(5-6): 1001-10. doi: 10.2166/wst.2017.062.

22. Jorfi S, Barzegar G, Ahmadi M, Darvishi Cheshmeh Soltani R, Alah Jafarzadeh Haghighifard N, Takdastan A, et al. Enhanced coagulation-photocatalytic treatment of acid red 73 dye and real textile wastewater using UVA/synthesized MgO nanoparticles. J Environ Manage 2016; 177: 111-8. doi: $10.1016 /$ j.jenvman.2016.04.005.

23. Rogers JA, Lagally MG, Nuzzo RG. Synthesis, assembly and applications of semiconductor nanomembranes. Nature 2011; 477(7362): 45-53. doi: 10.1038/nature10381.

24. Saravanan R, Sacari E, Gracia F, Khan MM, Mosquera E, Gupta VK. Conducting PANI stimulated $\mathrm{ZnO}$ system for visible light photocatalytic degradation of coloured dyes. J Mol Liq 2016; 221: 1029-33. doi: 10.1016/j. molliq.2016.06.074.

25. Goesmann H, Feldmann C. Nanoparticulate functional materials. Angew Chem Int Ed Engl 2010; 49(8): 1362-95. doi: 10.1002/anie.200903053.

26. Tian J, Zhao Z, Kumar A, Boughton RI, Liu H. Recent progress in design, synthesis, and applications of onedimensional $\mathrm{TiO} 2$ nanostructured surface heterostructures: a review. Chem Soc Rev 2014; 43(20): 6920-37. doi: 10.1039/ c4cs00180j.

27. Djurisic AB, Chen $\mathrm{X}$, Leung $\mathrm{YH}, \mathrm{Ng}$ AM. ZnO nanostructures: growth, properties and applications. J Mater Chem 2012; 22(14): 6526-35. doi: 10.1039/c2jm15548f.

28. Jorfi S, Samaei MR, Darvishi Cheshmeh Soltani R, Talaie Khozani A, Ahmadi M, Barzegar G, et al. Enhancement of the bioremediation of pyrene-contaminated soils using a hematite nanoparticle-based modified fenton oxidation in a sequenced approach. Soil Sediment Contam 2017; 26(2): 141-56. doi: 10.1080/15320383.2017.1255875.

29. Darvishi Cheshmeh Soltani R, Jorfi S, Safari M, Rajaei MS. Enhanced sonocatalysis of textile wastewater using bentonite-supported $\mathrm{ZnO}$ nanoparticles: response surface methodological approach. J Environ Manage 2016; 179: 4757. doi: 10.1016/j.jenvman.2016.05.001.

30. Darvishi Cheshmeh Soltani R, Rezaee A, Khataee AR, Safari M. Photocatalytic process by immobilized carbon black/ZnO nanocomposite for dye removal from aqueous medium: optimization by response surface methodology. J Ind Eng Chem 2014; 20(4): 1861-8. doi: 10.1016/j. jiec.2013.09.003.

31. Tan C, Gao N, Deng Y, Zhang Y, Sui M, Deng J, et al. Degradation of antipyrine by UV, UV/H2O2 and UV/ PS. J Hazard Mater 2013; 260: 1008-16. doi: 10.1016/j. jhazmat.2013.06.060.

32. Talaiekhozani A, Eskandari Z, Talaei MR, Salari M. Hydrogen sulfide and organic compounds removal in municipal wastewater using ferrate (VI) and ultraviolet radiation. Environ Health Eng Manag 2017; 4(1): 7-14. doi: 10.15171/ehem.2017.02.

33. Vinayagam M, Ramachandran S, Ramya V, Sivasamy A. Photocatalytic degradation of orange $\mathrm{G}$ dye using $\mathrm{ZnO} /$ biomass activated carbon nanocomposite. J Environ Chem Eng 2018; 6(3): 3726-34. doi: 10.1016/j.jece.2017.06.005.

34. Zuorro A, Lavecchia R. Evaluation of UV/H2O2 advanced oxidation process (AOP) for the degradation of diazo dye reactive green 19 in aqueous solution. Desalin Water Treat 2014; 52(7-9): 1571-7. doi: 10.1080/19443994.2013.787553.

35. Zita J, Krysa J, Mills A. Correlation of oxidative and reductive dye bleaching on $\mathrm{TiO} 2$ photocatalyst films. J Photochem Photobiol A Chem 2009; 203(2-3): 119-24. doi: 10.1016/j.jphotochem.2008.12.029.

36. Yang Y, Wyatt DT, Bahorsky M. Decolorization of dyes using UV/H2O2 photochemical oxidation. Textile Chemist and Colorist 1998; 30(4): 27-35.

37. Tichonovas M, Krugly E, Jankunaite D, Racys V, Martuzevicius D. Ozone-UV-catalysis based advanced oxidation process for wastewater treatment. Environ Sci Pollut Res Int 2017; 24(21): 17584-97. doi: 10.1007/s11356017-9381-y.

38. Talaiekhozani A, Salari M, Talaei MR, Bagheri M, Eskandari Z. Formaldehyde removal from wastewater and air by using UV, ferrate(VI) and UV/ferrate(VI). J Environ Manage 2016; 184(Pt 2): 204-9. doi: 10.1016/j.jenvman.2016.09.084.

39. Talaiekhozani A, Eskandari Z, Bagheri M, Talaie MR. Removal of H2S and COD using UV, ferrate and UV/ ferrate from municipal wastewater. Journal of Human, Environment and Health Promotion 2016; 2(1): 1-8. doi: 10.29252/jhehp.2.1.1.

40. Kalyani DC, Telke AA, Dhanve RS, Jadhav JP. Ecofriendly biodegradation and detoxification of reactive red 2 textile dye by newly isolated Pseudomonas sp. SUK1. J Hazard Mater 2009; 163(2-3): 735-42. doi: 10.1016/j. jhazmat.2008.07.020.

41. Eskandari Z, Talaiekhozani A, Makipoor G, Jafari S, Rezania S. Estimation of pollutants emission rate from activity of Isfahan city taxies. J Air Pollut Health 2017; 2(3): 137-44.

42. Honorio JF, Veit MT, Goncalves Gda C, de Campos EA, Fagundes Klen MR. Adsorption of reactive blue BF-5G dye by soybean hulls: kinetics, equilibrium and influencing factors. Water Sci Technol 2016; 73(5): 1166-74. doi: 10.2166/wst.2015.589.

43. Moussavi G, Mahmoudi M. Removal of azo and anthraquinone reactive dyes from industrial wastewaters using MgO nanoparticles. J Hazard Mater 2009; 168(2-3): 806-12. doi: 10.1016/j.jhazmat.2009.02.097.

44. Han Q, Wang H, Dong W, Liu T, Yin Y, Fan H. Degradation of bisphenol A by ferrate(VI) oxidation: kinetics, products and toxicity assessment. Chem Eng J 2015; 262: 34-40. doi: 10.1016/j.cej.2014.09.071.

45. Zhou Z, Jiang JQ. Reaction kinetics and oxidation products formation in the degradation of ciprofloxacin and ibuprofen by ferrate(VI). Chemosphere 2015; 119 Suppl: S95-100. doi: 10.1016/j.chemosphere.2014.04.006.

46. Li ZW, Gao W, Reeves RJ. Zinc oxide films by thermal oxidation of zinc thin films. Surf Coat Technol 2005; 198(13): 319-23. doi: 10.1016/j.surfcoat.2004.10.111.

47. Wang J, Gao L. Hydrothermal synthesis and photoluminescence properties of $\mathrm{ZnO}$ nanowires. Solid 
State Commun 2004; 132(3-4): 269-71. doi: 10.1016/j. ssc.2004.07.052.

48. Baratto C, Todros S, Faglia G, Comini E, Sberveglieri G, Lettieri $\mathrm{S}$, et al. Luminescence response of $\mathrm{ZnO}$ nanowires to gas adsorption. Sens Actuators B Chem 2009; 140(2): 461-6. doi: 10.1016/j.snb.2009.05.018.

49. Ren S, Bai YF, Chen J, Deng SZ, Xu NS, Wu QB, et al. Catalyst-free synthesis of $\mathrm{ZnO}$ nanowire arrays on zinc substrate by low temperature thermal oxidation. Mater Lett 2007; 61(3): 666-70. doi: 10.1016/j.matlet.2006.05.031.

50. Shahrezaei F, Mansouri Y, Zinatizadeh AA, Akhbari A. Photocatalytic degradation of aniline using $\mathrm{TiO} 2$ nanoparticles in a vertical circulating photocatalytic reactor. Int J Photoenergy 2012; 2012: 430638. doi: $10.1155 / 2012 / 430638$. 